\title{
Moral suffering in health professionals: portrait of the work environment in times of COVID-19
}

\author{
Sofrimento moral em profissionais de saúde: retrato do ambiente de trabalho em tempos de COVID-19 \\ Sufrimiento moral en profesionales de salud: retrato del ambiente de trabajo en tiempos de COVID-19
}

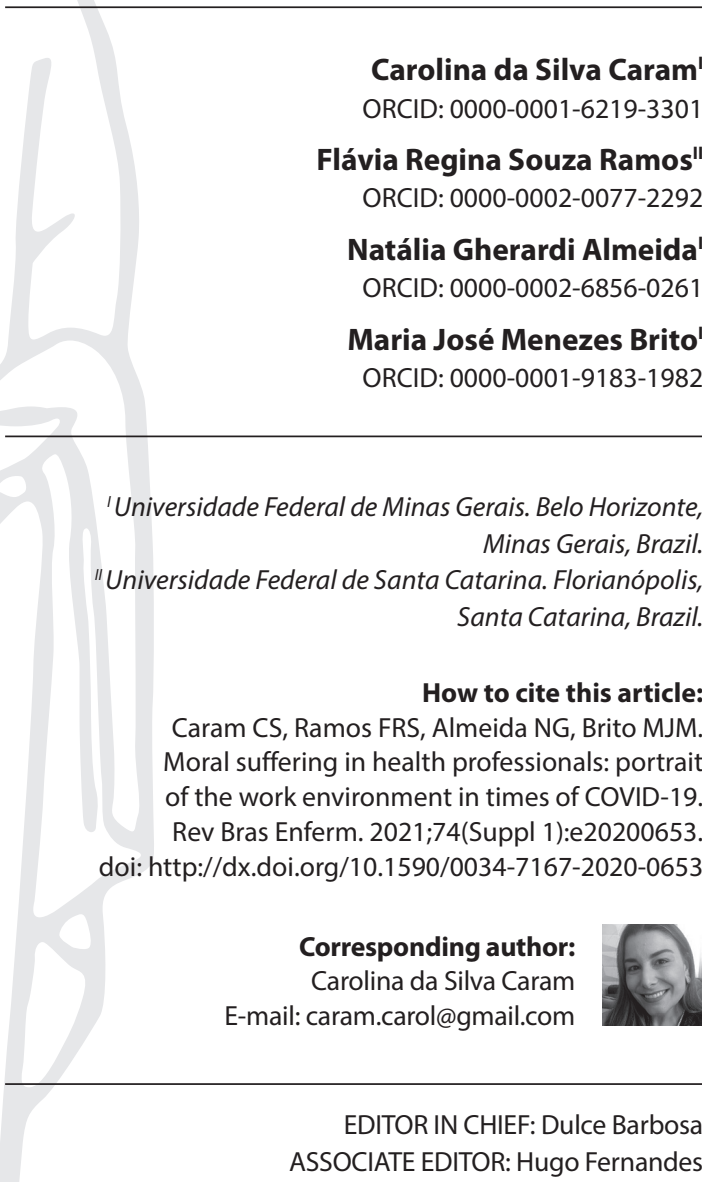

Submission: 06-12-2020

Approval: $10-31-2020$

\begin{abstract}
Objective: To analyze potential triggers of moral suffering experiences of health professionals, reported in the media, during the COVID-19 pandemic and to propose a theoretical construct of analysis. Methods: Study with qualitative approach whose data source were 50 reports published online, collected passively and actively, submitted to Content Analysis with the help of ATLAS.ti software. Results: The potential moral problems that trigger moral suffering are related to the threat to moral integrity, infrastructure/logistics and teamwork problems, and emotional aspects, revealing their articulation with damage to the foundations of a healthy work environment, which generated the proposal of a construct. Final considerations: The articulation between the experiences of moral suffering and the commitment of the fundamentals of a healthy work environment has brought important contributions to the adoption of strategies to protect and stimulate moral deliberation by professionals in favor of practice and society. Descriptors: Coronavirus Infections; Stress, Psychological; Working Environment; Health Personnel; Pandemic.
\end{abstract}

\section{RESUMO}

Objetivo: Analisar potenciais desencadeadores de vivências de sofrimento moral de profissionais da saúde, veiculadas nas mídias, durante a pandemia de COVID-19 e propor um constructo teórico de análise. Métodos: Estudo com abordagem qualitativa cuja fonte dos dados foram 50 reportagens publicadas on-line, coletadas de forma passiva e ativa, submetidas à Análise de Conteúdo com auxílio do software ATLAS.ti. Resultados: Os potenciais problemas morais desencadeadores de sofrimento moral relacionam-se à ameaça à integridade moral, aos problemas de infraestrutura/logística e da equipe de trabalho e aos aspectos emocionais, revelando sua articulação com prejuízos aos fundamentos do ambiente de trabalho saudável, o que gerou a proposta de um constructo. Considerações finais: A articulação entre as vivências de sofrimento moral e o comprometimento dos fundamentos do ambiente de trabalho saudável trouxe importantes contribuições para a adoção de estratégias de proteção e de estímulo à deliberação moral pelos profissionais em favor da prática e da sociedade.

Descritores: COVID-19; Sofrimento Moral; Ambiente de Trabalho; Profissionais de Saúde; Pandemia.

\section{RESUMEN}

Objetivo: Analizar potenciales desencadenadores de experiencias de sufrimiento moral de profesionales de salud, vehiculadas en los medios, durante la pandemia de COVID-19 y proponer un constructo teórico de análisis. Métodos: Estudio con abordaje cualitativo cuya fuente de datos fueron 50 reportajes publicados online, recogidos de forma pasiva y activa, sometidas al Análisis de Contenido con auxilio del software ATLAS.ti. Resultados: Potenciales problemas morales desencadenadores de sufrimiento moral se relacionan a amenaza a integridad moral, a problemas de infraestructura/logística y del equipo de trabajo y a aspectos emocionales, revelando su articulación con perjuicios a fundamentos del ambiente de trabajo saludable, lo que generó la propuesta de un constructo. Consideraciones finales: Articulación entre experiencias de sufrimiento moral y comprometimiento de fundamentos del ambiente de trabajo saludable trajo importantes contribuciones para adopción de estrategias de protección y de estímulo a deliberación moral por profesionales en favor de la práctica y de la sociedad. Descriptores: COVID-19; Sufrimiento Moral; Ambiente de Trabajo; Profesionales de Salud; Pandemia. 


\section{INTRODUCTION}

The World Health Organization (WHO) decreed on March 11, 2020, the COVID-19 pandemic. It is an acute respiratory infectious disease, transmitted mainly by the respiratory tract, droplets, respiratory secretions and direct contact. An effectively proven therapy for COVID-19 is not yet known, and the treatment focuses on symptomatic and respiratory support ${ }^{(1)}$. The first cases of infection with the new coronavirus occurred in China in 2019, spreading rapidly to other countries. In Brazil, the first confirmed case occurred on February 26, 2020; and in about three months of spread, more than 500,000 cases and almost 30,000 deaths were confirmed $^{(2)}$. Overall, there were about 6 million confirmed cases and 360 thousand deaths in this period ${ }^{(3)}$.

The disease has overwhelmed health systems around the world, exposing several problems related to the quantity of beds, personal protective equipment (PPE) and health professionals ${ }^{(4-5)}$. Especially regarding the performance of health professionals in the front line of care for contaminated patients, the pandemic has brought important challenges in Brazil and the world. Many of these challenges hurt the moral integrity of these professionals, given the ethical issues related to the death of vulnerable people; limited amount of testing and the risk of contamination; scarcity of structural resources and protective equipment to offer quality and safe care; lack of support from leaders; lack of emotional and psychological preparation for the consequences of decisions made; and lack of social support ${ }^{(4-5)}$.

Therefore, it is perceived that the performance on the front against the coronavirus is configured as exposure to risks of illness and wear for health professionals, as well as experiences of moral suffering (MS). The MS is triggered when the professional perceives a moral problem in his daily work, makes his judgment, but is unable to act in accordance with their moral values $^{(6)}$. Therefore, the MS is characterized by the powerlessness to act according to its ethical-moral positioning in a given situation, making impossible the course of moral deliberation, that is, considered "the most correct moral action - intrinsic to the practice of excellence ${ }^{\prime \prime(6)}$. Considering that experiences in health services, in times of pandemic, can hurt the moral integrity of professionals and generate MS, affecting their safety, health and well-being, it is necessary to invest in conditions favorable to moral deliberation, which will impact on the quality of care provided and also in the work environment.

The reality of health professionals in the care of patients during the COVID-19 pandemic has been reported in different ways in the mass media. By portraying everyday issues, the media are responsible for building people's perceptions and creating social realities, since they provide the content that will be the basis of individual and collective thinking. According to the theory of social representation, the media is one of the ways of building knowledge and representations, defining the social perception of what is true ${ }^{(7)}$.

Regardless of the reference adopted to treat mass communication, there is the recognition of a pandemic as a cultural phenomenon, which engenders narratives and inscriptions of the facts in possible symbolic orders ${ }^{(8)}$. The importance of the narratives conveyed in the media becomes more remarkable at a time designed by an abundance of information, disclosed at hyper speed and with limited filtering, mixing facts, speculation and disinformation, called info-pandemic ${ }^{(910)}$."Infodemia" involving COVID-19 is now also considered a public health problem ${ }^{(11)}$.

As the global concern with the pandemic grew, both traditional media (television, radio, newspapers in print and digital media) and social media began to highlight information regarding the experiences of health professionals. Among the diverse problems brought to the public, society became aware of ethical issues experienced in the work environment by health professionals, providing the necessary reflection on the moral suffering and the need to prioritize the safety, health and well-being of these workers during the pandemic.

In view of the considerations presented and the relevance of the media when publishing about the factors that may trigger experiences of moral suffering by health professionals during the COVID-19 pandemic, questions arise about the dissemination of these experiences based on these sources of information, given their potential for reach and repercussion in society. It is assumed that the sources, which gather statements, interpretations and accounts by third parties, are not necessarily based on an appropriation of the concept of moral suffering, being possible to analyze them only as potentially linked to the experience of moral suffering. Thus, understanding that the object of this study refers to the potential triggers of moral suffering experiences portrayed in the media, it may provide important subsidies to rethink the work and context of action of health professionals.

\section{OBJECTIVE}

To analyze potential triggers of moral suffering experiences of health professionals, reported in the media, during the COVID-19 pandemic and to propose a theoretical construct of analysis.

\section{METHODS}

\section{Ethical aspects}

This investigation did not require appreciation by the Committee of Ethics in Research, since the reports used as a corpus of data analyzed are available in a public way and with free access to information.

\section{Type of study and study scenario}

It is a study with a qualitative approach, guided by documentary, exploratory and interpretative research. Such approach allows the adoption of different techniques depending on the perspective of the researcher in order to incorporate the subjective meaning of social structures ${ }^{(12)}$.

The analysis of potential triggers of moral suffering of health professionals during the COVID-19 pandemic was carried out, based on news and reports broadcast by online media that addressed the issue of health professionals in the care of patients and family members on the occasion of the pandemic.

This study followed the guidelines of the Standards for Reporting Qualitative Research (SRQR) report ${ }^{(13)}$, to ensure the article's adequacy to the standard of transparency for reporting results in qualitative researches. 


\section{Data sources}

The source of the data was the content of the reports/news published online. The choice of these reports and news were made according to the following inclusion criteria: the publication took place after the WHO decree of the pandemic, on March 11, 2020; it was published in magazines and/or newspapers with national or international circulation with information about Brazil and the world; and it was available online and free of charge. The exclusion criteria for reports and news were: to present empirical data from articles published in scientific periods; to have the format of presentation in video-reportage; and, finally, not to address potential triggers of experiences of moral suffering.

\section{Data collection and organization}

The data collection was carried out between March 27 and 30,2020 , capturing reports broadcasted between the 11 th and 30th of the same month. The search and selection of news and reports took place in a passive and active way. The passive form was carried out by means of reports and news received via instant messaging application by the authors of this article. The active form occurred by consulting the Google search site, using in a combined and isolated way the following keywords: health professionals, health service, suffering, pandemic, COVID-19 and coronavirus. Considering the inclusion criteria and after the raw research of the materials, 63 reports/news were selected. Then, they were read in full; and, applying the exclusion criteria, 19 of them were discarded, totaling a sample of 44 reports/news. It should be noted that four reports that had restricted access to subscribers were excluded; four reports that addressed empirical results of articles published in scientific journals; four repeated reports; one report whose format was video; and six reports that did not contain reports of potential triggers of moral suffering by health professionals. The large number of reports in 19 days of dissemination allowed us to see the qualitative saturation of the data, that is, a repetition of the themes and not the addition of new elements of content.

The data was organized in a systematic way, using the Excel ${ }^{\circledR}$ 2016 program, being organized with numerical identification of the report, name of the magazine, title of the report, date of publication, link to the report on the web and findings related to the triggering factors of experiences of moral suffering.

\section{Data analysis}

The data analysis followed the three chronological poles of the Content Analysis proposed by Bardin ${ }^{(14)}$, with the help of ATLAS. ti 7.5.9 software. This analysis is based on the content expressed in words, relating semantic structures (signifiers) to sociological structures (meanings), considering the context in which such content is built, in a process of differentiation and regrouping ${ }^{(14)}$. ATLAS.ti software is a tool compatible with qualitative researches ${ }^{(15)}$ which assists the researcher in organizing the data and requires him/her to effectively act during the software manipulation.

The chronological poles of the Content Analysis were: preanalysis; exploration of the material; treatment of the results, inference and interpretation ${ }^{(14)}$. The pre-analysis concerns the organization and floating reading of the material, with the purpose of assimilating it, having been carried out on the website that made the news or report available. After the reading, the content obtained was inserted in the software, composing the hermeneutic unit of the study and delimiting the corpus. The exploration of the material consisted in the codification and categorization of the corpus, which, in the codification stage, was transformed into units of representation and content, organized in the ATLAS.ti software into codes and quotas, respectively. In the categorization stage, the representation units (codes) were grouped by similarity, according to criteria of repetition and relevance, considering potential triggers of moral suffering, in order to compose in the software, the family, which are: emotional aspects; problems of infrastructure and logistics; and fragility in moral integrity. The treatment of results, inference and interpretation consisted in deepening the analysis, establishing connections with the theoretical framework on moral suffering ${ }^{(14)}$. By deepening the reading of the material, it was identified an important relationship between the factors that triggered the experience of moral suffering categorized in the previous stage and the work environment in which these professionals worked, which led them to assume this relationship for data analysis purposes. Therefore, the basic components of the Healthy Work Environment model were considered, as proposed by the World Health Organization $(\mathrm{WHO})^{(16)}$, namely: Psychosocial environment; Physical work environment; Resources for personal health; and Company participation in the community. In the latter, the term "service" was adopted, replacing the "company". In order to guarantee reliability and reliability, triangulation in the analysis was performed by three authors at different times.

\section{RESULTS}

The factors that trigger moral suffering and its interrelationship with the healthy work environment are summarized in Chart 1.

Twenty-three codes were selected in the ATLAS.ti software, representing 366 quotations. The codes were regrouped according to their thematic similarities, leading to the proposition of four categories (family): Emotional aspects (10 codes); Infrastructure and logistics problems (4 codes); Work team problems ( 4 codes) and; Threats to moral integrity (5 codes). After this stage of the analysis process, the codes that presented the potential causes of moral suffering portrayed in all fragments of the reports and news (quotations) were related to the dimensions of the Healthy Work Environment (HWE) model and to the construction of moral suffering ${ }^{(6)}$, conceived as a process that integrates the ideas of sensitivity, discomfort and moral uncertainty (conditions for the subject to discover a moral problem) and of moral deliberation. The latter involves the analysis of the problem and of the alternatives to face it, the election of the most correct or prudent alternative and its evaluation after the consequent action; and that, when obstructed or impeded from materializing (guiding the action), causes moral suffering - impossibility to act according to its moral judgment. The relationship obtained between the crossing of the three thematic categories, which represent the causes of moral suffering, and the dimensions of HWE is represented in Figure 1. 
Chart 1 - Interrelationship between factors that trigger moral suffering and the healthy work environment, Belo Horizonte, Minas Gerais, Brazil, 2020

\begin{tabular}{|c|c|c|}
\hline $\begin{array}{l}\text { HWE } \\
\text { DIMENSIONS }\end{array}$ & $\begin{array}{l}\text { FAMILY } \\
\text { (categories) }\end{array}$ & CODES/QUOTATIONS \\
\hline \multirow{4}{*}{$\begin{array}{l}\text { Physical work } \\
\text { environment }\end{array}$} & \multirow{4}{*}{$\begin{array}{l}\text { Infrastructure } \\
\text { and logistics } \\
\text { problems }\end{array}$} & Scarcity of PPE (59) \\
\hline & & Infrastructure problems (24) \\
\hline & & Scarcity of diagnostic tests (9) \\
\hline & & Scarcity of equipment (8) \\
\hline \multirow{4}{*}{$\begin{array}{l}\text { Resources } \\
\text { for personal } \\
\text { health }\end{array}$} & \multirow{4}{*}{$\begin{array}{l}\text { Work team } \\
\text { problems }\end{array}$} & Risk of contagion (19) \\
\hline & & Shortage of personnel (13) \\
\hline & & Disinformation (10) \\
\hline & & Lack of training (6) \\
\hline \multirow{11}{*}{$\begin{array}{l}\text { Psychosocial } \\
\text { environment }\end{array}$} & \multirow{5}{*}{$\begin{array}{l}\text { Threats } \\
\text { to moral } \\
\text { integrity }\end{array}$} & Commitment to professional security (30) \\
\hline & & Ethical dilemmas (14) \\
\hline & & Impotence (13) \\
\hline & & Moral obligation with the service (10) \\
\hline & & Damage to the quality of care (8) \\
\hline & \multirow{10}{*}{$\begin{array}{l}\text { Emotional } \\
\text { aspects }\end{array}$} & Anguish in the face of uncertainties (26) \\
\hline & & Fear of contagion (22) \\
\hline & & Stress (18) \\
\hline & & Psychological problems (10) \\
\hline & & Dealing with death (6) \\
\hline & & Negative feelings (6) \\
\hline \multirow{4}{*}{$\begin{array}{l}\text { Involvement } \\
\text { of service } \\
\text { in the } \\
\text { community }\end{array}$} & & Fear of transmitting the virus (21) \\
\hline & & Family Affiliation (18) \\
\hline & & Weakened interpersonal relationships (8) \\
\hline & & Violence (8) \\
\hline
\end{tabular}

The articulation between the theoretical constructs of moral suffering and HWE is considered bilateral and reciprocal, and therefore there is no cause and effect or hierarchy relationship between the two. It is important to point out that the existence of a moral problem is the trigger that produces moral judgments. The component of the figure on the left concerns the WHO proposal to characterize the dimensions of the HWE: Psychosocial environment; Physical work environment; Resources for personal health; and Participation of the company (service) in the community. Articulating them with the thematic categories (family) organized to represent potential experiences of moral suffering, the category "Emotional aspects" is related to the Psychosocial Work Environment ( 6 codes) and the Involvement of Service in the Community (4 codes). The category "Infrastructure and logistics problems" is related to the dimension "Physical work environment" (4 codes); and the category "Work team problems" is related to the dimension "Resources for personal health" (4 codes). Finally, the category "Threats to moral integrity" relates to the Psychosocial Environment (5 codes).

\section{DISCUSSION}

Through the analysis of the data, the interrelationship between the factors potentially causing moral suffering and the dimensions of the Healthy Work Environment (HWE) was observed. Therefore, it is inferred that all thematic categories (family) represent moral problems with potential to trigger experiences of moral suffering by health professionals. Furthermore, it is understood that the process of moral suffering can affect the values that underpin the healthy work environment, compromising safety, health and well-being at work.

The construction of moral suffering was based on the conceptual framework developed in a multi-centric study that highlights its procedural nature. Moral suffering is part of the human experience and occurs in situations in which the subject encounters, in daily work, a moral problem that requires its ethical positioning $^{(6)}$. The moral problem is, therefore, the trigger that triggers the process in which discomfort, sensitivity and moral uncertainty mobilize the professional to make the moral judgment on the issue in focus. The outcome of the moral suffering only materializes if the professional is prevented from deliberating morally, understanding that the completeness of the deliberation process only occurs after the action/decision is taken and its evaluation.

It is important to stress that the moral problem is not perceived in the same way by all professionals, depending on ethical-moral skills and one's own moral sensitivity for analyzing the problem ${ }^{(6)}$.
Figure 1 - Schematic representation of the theoretical articulation between the study categories (moral suffering) and Healthy Work Environment, Belo Horizonte, Minas Gerais, Brazil, 2020 
Although they perceive moral problems differently, precarious situations or adverse working environment conditions are common among professionals, and these can trigger experiences of moral suffering ${ }^{(17)}$.

The reality of the pandemic has brought new challenges and restrictions to health services, causing negative concerns and feelings in the professionals who work in these services, such as the risk of contagion, isolation, fear and anxiety ${ }^{(18)}$. The challenge becomes even more complex if we consider that they need to seek a balance between their physical and mental needs and those of patients ${ }^{(19)}$. In this sense, health organizations need to deal with the psychological and psychosocial consequences of this moment ${ }^{(20)}$, which may cause moral damage to those workers ${ }^{(4)}$, in line with the results of this study. Therefore, it is realized that limits and obstacles directly related to the work environment can prevent the adequate resolution of problems, generating moral suffering. Thus, the initial discomfort and moral uncertainty do not direct the professional towards the course of action morally evaluated as correct, development of his moral agency or expressiveness as moral subject.

According to WHO, HWE is one in which professionals and managers "collaborate for the use of a process of continuous improvement in the protection and promotion of the safety, health and well-being of all workers and for the sustainability of the working environment"(16). HWE consists of a multidimensional model that involves physical and psychosocial conditions of work, resources for personal health and company involvement (service) in the community ${ }^{(16)}$, It is a structured set that influences the way professionals experience the ethical-moral issues that present themselves in daily life. Figure 1 presents the connection and relationship between HWE and the dynamics of perception of the moral problem. Physical, biological, psychosocial and those dangers that affect resources for personal health and community involvement impact safety, health and well-being at work ${ }^{(16)}$.

The infrastructure and logistics problems presented by the media are related to the dimensions of the physical work environment and the Resources for personal health. The Physical Work Environment dimension encompasses the structure, materials and production processes. The related hazards are chemical, physical, ergonomic, biological, mechanical and others, and can lead to disability and death of the professional ${ }^{(16)}$. In this regard, the data revealed the lack of diagnostic tests, PPE and equipment, as well as infrastructure problems. About the scarcity of materials and inputs to attend the coronavirus, studies indicate that the pandemic requires the use, in addition to the installed capacity, of inputs and equipment such as ventilators, masks, gloves, drugs and others, generating concern in health professionals about the risk of contagion and the safety of assistance provided ${ }^{(21-23)}$.

In order to minimize the physical risks to which health professionals are exposed during the period of the COVID-19 pandemic, authors point out the need to define transparent and equitable policies for the distribution of inputs by health services, since the ideal conditions will have to be reviewed and the decisions taken will be decisive for experiences of moral suffering ${ }^{(21-23)}$. In the data collection period of the present study, the scarcity of PPE was the most cited item in news and reports. In this regard, authors mention rationing strategies based on the utilitarian principle of principalist ethics ${ }^{(21)}$. For this, the actions should seek the best for the greatest number of people, considering their social value. Among these actions, we highlight: use the minimum possible protection for a certain procedure; avoid unnecessary professionals in areas that require PPE and; offer equipment for the professional with the highest chance of saving more people ${ }^{(21)}$.

Infrastructure and logistics issues related to the Personal Health Resources dimension relate to the components that support the worker in committing their efforts at work while maintaining a healthy lifestyle, such as access to information, personal resources, materials and others ${ }^{(16)}$. The results showed that the problems related to this dimension involve misinformation, shortage of personnel, lack of training and risk of contagion. The importance of human resources in health during the crisis is not limited to quantitative terms, but includes the ability of professionals to act in prolonged times and exposed to risks of contamination and emotional stressors ${ }^{(24-25)}$. This is because they do not feel technically prepared to act and run the risk of contaminating themselves and their families. Therefore, it is important to prepare and support health professionals through the present, sensitive and proactive action of the leaderships, sharing decision making, and also actions directed towards listening, transparent communication, protection at work (rest and decompression times), implementation of protocols, training and health education, as well as social and health support for workers and their families ${ }^{(24-25)}$.

The emotional aspects identified in the researched media are linked to the psychosocial work environment and community service involvement dimensions. The involvement or relationship of the service (company) with the community interferes with the well-being and physical and mental health of workers and their families $^{(16)}$, Since the way these workers are seen, supported or rejected by society is an important element for their own selfimage, and may or may not generate feelings of gratification, appreciation, respect and recognition. The emergence of the pandemic has pointed to a paradoxical phenomenon. On one hand, there is what is described as "the hand that has now assaulted applauds", i.e., a broad and worldwide appreciation of health professionals, who from a situation of assaulted people (victims of violence at some point in their work trajectory) become heroes $^{(26)}$. On the other hand, despite the wide visibility of the relevance of their work, professionals have also come to be seen as a danger or source of contagion in their rare contacts, such as in means of transportation or residential buildings. The results related to this dimension pointed to family remoteness, the fear of being a transmitter of the virus, the fragility of interpersonal relationships and the violence suffered. Specifically, the latter refers to manifestations by the closest social environment, in what could be expressed as "I applaud you, but stay away from me". The other manifestations refer to feelings and momentary losses of the professional in relation to his/her family and social life.

The way health professionals in the front line of the fight against the coronavirus experience quarantine presents particularities. While the population experiences social isolation with people who share the same residence, health professionals face the moral dilemma between going home, taking with them the possibility of transmitting the virus, or practicing distance from their relatives in order to keep them protected. This situation of isolation and 
confinement of health professionals is pointed out as a source of suffering and stress ${ }^{(27)}$. Social networks and technologies have brought important contributions in psychological counseling, as well as in bringing people together at this time, despite being sometimes a source of fake news and dissemination of negative meanings and fears ${ }^{(27)}$. Entities, such as the Federal Nursing Council, have taken initiatives for Live Chat care by mental health specialist nurses. In these services, situations of anxiety, stress, fear, ambivalence, depression and exhaustion were declared. Among the sources of such manifestations are some related to relations with society, such as anxiety caused by news made available by the media, ambivalence motivated by the population (neighbors, friends) who applaud but discriminate against them and avoid them, or depression linked to loneliness and remoteness from families, in addition to the death of co-workers ${ }^{(28)}$.

Tensions and controversies among health authorities, researchers, health professionals, thinkers with diverse logics (within economics, politics, human rights, among other areas) contribute to misinformation, which impacts the relationship between services, professionals and the community. Moreover, the asymmetry of information exacerbates inequality, with different conditions of use, production and dissemination of information, under the filter of public use of reason in times of dramatic approach to the horizon of human finitude ${ }^{(29)}$.

Other results regarding the emotional aspects were related to the psychosocial dimension, revealed by feelings of anguish stemming from uncertainties inherent to the moment, stress, proximity to death, fear of contagion, psychological problems and other negative feelings. This dimension covers the organizational culture, values, beliefs and practices that influence the physical and mental well-being of workers ${ }^{(16)}$. The COVID-19 pandemic circumstance brings feelings such as anxiety, stress and fear to the general population and to health professionals, the latter being pressured to trigger resilience mechanisms to cope with the entire workload and provide assistance to patients ${ }^{(30)}$.

Negative feelings are the first signs of the possibility of experiencing moral suffering, occurring in the first phase represented in Figure 1, in which discomfort and recognition of the moral problem occur ${ }^{(6)}$. Especially in the pandemic, professionals are dealing with ethical issues already mentioned, such as lack of equipment, overload of work, training and adherence of the population to precautionary measures, which makes them more likely to experience negative feelings, psychological problems and moral suffering ${ }^{(31-32)}$. The fear that professionals feel of being contaminated, identified in news and reports, is real, considering that they represent one of the most vulnerable populations for the contraction of the disease ${ }^{(25,28)}$. In addition, they are coping and facing death on a daily basis, which exacerbates the level of stress experienced in caring for contaminated patients ${ }^{(28,32)}$. In this sense, it is important that service leaders develop strategies for intervention and psychological care for professionals in order to promote their mental health and provide improvements in the working environment.

The problem of fragility in the moral integrity of professionals is related to the dimension of the psychosocial work environment, which includes values and beliefs that influence the experiences of professionals. The results of this study indicate that threats to the moral integrity of professionals refer to situations that assault and weaken their values and principles, such as in cases of damage to the quality of assistance, harassment suffered regarding their safety, ethical dilemmas and powerlessness, especially in view of their sense of responsibility and moral obligation with the service.

Furthermore, the reports portray intimidation on the part of the institutions, when decisions are imposed on the availability of PPE and work organization that do not protect professionals from contamination and compromise their safety. The reality of the lack of infrastructure and logistics places them among the most susceptible to contamination ${ }^{(25)}$. In this context, they face ethical dilemmas regarding the best practices to be adopted to offer safe assistance to both (to themselves and to the patient), since scientific evidence on the behavior of the virus, treatments and actions involved are still being produced.

The situation described is challenging for health professionals, who are being pressured to give immediate and adequate responses with the best practices regarding treatment and prevention, being feasible and in the short term, while suffering from overload, exposure, frustration and exhaustion ${ }^{(18)}$. The findings of the present study corroborate such analysis, considering that the information contained in the media analyzed pointed out that the professionals understand as a moral obligation to act ethically and efficiently in the care of infected patients, because it is the profession they have chosen. At the same time, these professionals question their exposure to contamination and excessive workload, establishing the impasse between their professional duty and the feeling of fear and insecurity.

The problems that undermine the moral integrity of professionals prevent the adoption of practices consistent with their values and beliefs ${ }^{(17)}$, which becomes a danger to the maintenance of a healthy psychosocial environment and can affect your physical and mental well-being ${ }^{(16)}$ and cause them moral suffering ${ }^{(17)}$.

The moral problems presented in this study as possible triggers to trigger experiences of moral suffering can be considered as contextual restrictions in the work environment that prevent action consistent with moral judgment. In large part, these factors are related to the organizational culture that does not support the moral deliberation of professionals, which can be avoided and is subject to modifications through concrete institutional actions ${ }^{(17)}$.

\section{Study limitations}

The limitations of the findings of this study refer to the time clipping of news and interviews, i.e., the beginning of the pandemic in the world. This circumstance may have provided positions affected by the emotional state of the authors, which, with the experience of this reality and the learning that it offers, may have been alleviated. This suggests that new studies should be carried out so that the entire period of the pandemic is contemplated, in its learning and adaptation phases, as well as empirical and intervention studies.

\section{Contributions to the area of Nursing, Health or Public Policy}

By articulating the potential factors that generate moral suffering to the scheme described by WHO on the healthy work environment, it is possible to propose pathways for interventions, 
promoting protection against moral suffering experiences by health professionals in the context of the COVID-19 pandemic. In this sense, it is possible to provide working environments that favor moral deliberation by these workers on behalf of patients and themselves, adopting the best practices in favor of society.

\section{FINAL CONSIDERATIONS}

The results of this study, extracted from news and reports on the COVID-19 pandemic in the health services, pointed not only to the existence of new moral problems, but also highlighted those that were already a reality in those services. Thus, it was perceived that moral problems that can trigger experiences of moral suffering have an intrinsic relationship with the commitment of the components of the healthy work environment, as proposed by WHO. In this sense, the present study advanced the proposition of a model that articulated the two constructs, which are related in a bilateral and reciprocal manner.

This articulation was achieved through a theoretical construct of analysis that contributes to the advancement of knowledge regarding the theoretical framework on moral suffering, adding important elements related to the values that underpin the working environment, as well as adding an ethical perspective in the reflection on the healthy working environment stimulated by $\mathrm{WHO}$.

It is important to emphasize that analyzing potential triggers of moral suffering experiences and articulating them with the healthy work environment model allows insights on the interventions needed in times of pandemic to protect workers from this type of experience. It is important to emphasize that efforts in this direction are relevant for health professionals to be able to deliberate morally in favor of patients and themselves, adopting practices consistent with the real social need at this time of humanitarian crisis.

\section{FUNDING}

Conselho Nacional de Desenvolvimento Científico e Tecnológico (CNPq); Coordenação de Aperfeiçoamento de Pessoal de Nível Superior (CAPES); Fundação de Amparo à Pesquisa de Minas Gerais (FAPEMIG).

\section{REFERENCES}

1. Yan-Rong G, Qing-Dong C, Zhong-Si H, Yuan-Yang T, Shou-Deng C, Hong-Jun J, et al. The origin, transmission and clinical therapies on coronavirus disease 2019 (COVID-19) outbreak: an update on the status. Mil Med Res. 2020;7(11):1-10. doi: 10.1186/s40779-020-00240-0

2. Ministério da saúde (BR). Painel Coronavírus. Hist_Painel_Covidbr[Internet]. 2020 [cited 2020 jun 10]. Available from: https://covid.saude.gov.br/

3. World Health Organization (WHO). Coronavirus disease (COVID-19): situation report -132 [Internet]. 2020 [cited 2020 Jun 10]. Available from: https://www.who.int/docs/default-source/coronaviruse/situation-reports/20200531-covid-19-sitrep-132.pdf?sfvrsn=d9c2eaef_2

4. Williamson V, Murphy D, Greenberg N. COVID-19 and experiences of moral injury in front-line key workers. Occup Med (Lond). 2020;70(5):317-319. doi: 10.1093/occmed/kqaa052

5. Misra DP, Agarwal V. To Act.......or to wait for the evidence: ethics in the time of covid-19! Indian J Rheumatol. 2020;15(1):3-4. doi: 10.4103/ injr.injr_53_20

6. Ramos FRS, Barlem ELD, Brito MJM, Vargas MA, Schneider DG, Brehmer LCF. Conceptual framework for the study of moral distress in nurses. Texto Contexto Enferm. 2016;25(2):1-10. doi: 10.1590/0104-07072016004460015

7. Mendonça RF, Braga CF. Representações midiáticas e representações sociais: a mídia e a construção da realidade social. Rev Communicatium [Internet]. 2016 [cited 2020 Jun 01];01(01):8-17. Available from: http://www.communicatium.com.br/index.php/ communicatium/article/viewFile/16/7

8. Lifschitz JA. Pandemia: qual biopolítica? In: Augusto CB, Santos RD (Orgs). Pandemias e pandemônio no Brasil. São Paulo: Tirant lo Blanch; 2020. 88-89p.

9. Pulido CM, Villarejo-Carballido B, Redondo-Sama G, Gómez A. COVID-19 infodemic: more retweets for science-based information on coronavirus than for false information. International Sociology. 2020;35(4):377-92. doi:10.1177/0268580920914755

10. Ruffell D. Coronavirus SARS -CoV-2: filtering out fact from fiction in the infodemic. FEBS Lett. 2020;594(1):1127-1131. doi: 10.1002/1873-3468.13784

11. Zarocostas J. How to fight an infodemic. Lancet. 2020;395(10225):676. doi:10.1016/s0140-6736(20)30461-x

12. Minayo MCDS, Costa AP. Fundamentos Teóricos das Técnicas de Investigação Qualitativa. Rev Lusófona Educ [Internet]. 2018[cited 2019 Dec 18];40(40):139-53. Available from: https://revistas.ulusofona.pt/index.php/rleducacao/article/view/6439

13. O'Brien BC, Harris IB, Beckman TJ, Reed DA, Cook DA. Standards for reporting qualitative research: a synthesis of recommendations. Acad Med. 2014;89(9):1245-1251. doi: 10.1097/ACM.0000000000000388

14. Bardin L. Análise de conteúdo. Edição Revista e Atualizada. Lisboa: Edições 70; 2011, 280p.

15. Brito MJM, Caram CS, Montenegro LC, Rezende LC, Rennó HMS, Ramos FRS. Potentialities of Atlas.ti for Data Analysis in Qualitative Research in Nursing. In: Costa AP, Reis LPR, Sousa FN, Moreira A, Lamas D (editors) Computer Supported Qualitative Research. Studies in Systems, Decision and Control. 2016;71(1):75-84. doi:10.1007/978-3-319-43271-7_7.

16. Organização Mundial da Saúde. Ambientes de trabalho saudáveis: um modelo para ação: para empregadores, trabalhadores, formuladores de política e profissionais [Internet]. 2010 [cited 2018 May 15]. 26p. Available from: https://www.who.int/occupational_health/ambientes_ de_trabalho.pdf?ua=1 
17. Woods M. Moral distress revisited: the viewpoints and responses of nurses. Int Nurs Rev. 2020;67(1):68-75. doi:10.1111/inr.12545

18. Lijun K, Yi L, Shaohua Hu, Min C, Can Y, Bing XY, et al. The mental health of medical workers in Wuhan, China dealing with the 2019 novel coronavirus. Lancet Psychiatr. 2020;7(3):e14. doi: 10.1016/S2215-0366(20)30047-X

19. Greenberg N, Docherty M, Gnanapragasam S, Wessely S. Managing mental health challenges faced by healthcare workers during covid-19 pandemic. BMJ. 2020;368:m1211. doi: 10.1136/bmj.m1211

20. Burdorf A, Porru F, Rugulies R. The COVID-19 (Coronavirus) pandemic: consequences for occupational health. Scand J Work Environ Health. 2020;46 (3):229-230. doi: 10.5271/sjweh.3893

21. Binkley CE, Kemp DS. Ethical rationing of personal protective equipment to minimize moral residue during the COVID-19 Pandemic. J Am Coll Surg. 2020;230(6):1111-13. doi:10.1016/j.jamcollsurg.2020.03.031

22. White DB, Lo B. A framework for rationing ventilators and critical care beds during the COVID-19 Pandemic. JAMA. 2020;323(18):1773-74. doi: 10.1001/jama.2020.5046

23. Jianbo L, Simeng M, Ying W, Zhongxiang C, Jianbo H, Ning W et al. Factors associated with mental health outcomes among health care workers exposed to Coronavirus Disease 2019. JAMA Netw Open. 2020;3(3):e203976. doi:10.1001/jamanetworkopen.2020.3976

24. Shanafelt T, Ripp J, Trockel M. Understanding and addressing sources of anxiety among health care professionals during the COVID-19 Pandemic. JAMA. 2020;323(21):2133-2134. doi:10.1001/jama.2020.5893

25. Adams JG, Walls RM. Supporting the health care workforce during the COVID-19 Global Epidemic. JAMA. 2020;323(15):1439-1440. doi:10.1001/jama.2020.3972

26. Passos L, Prazeres F. A Mão que agrediu agora aplaude: a imagem dos profissionais de saúde frente à pandemia COVID-19. Gazeta Méd [Internet]. 2020[cited 2020 Jun 07]. Available from: https://www.researchgate.net/ publication/340686564_A_Mao_que_Agrediu_Agora_Aplaude_A_Imagem_dos_Profissionais_de_Saude_Frente_a_Pandemia_COVID-19

27. Cruz RM, Borges-Andrade JE, Moscon DCB, Micheletto MRD, Esteves GGL, Delben PBa, et al. COVID-19: emergência e impactos na saúde e no trabalho. Rev Psicol Organ Trab. 2020;20(2):I-III. doi:10.17652/rpot/2020.2.editorial

28. Humerez DC, OhI RIB, Silva MCN. Saúde mental dos profissionais de enfermagem do Brasil no contexto da pandemia Covid-19: ação do Conselho Federal de Enfermagem. Cogitare Enferm. 2020;25:e74115. doi: dx.doi.org/10.5380/ce.v25i0.74115

29. Lima CRM de, Sánchez-Tarragó N, Moraes D, Grings L, Maia MR. Global public health emergency due to the COVID-19 pandemic: disinformation, information asymmetry and discursive validation. Rev Folha Rosto [Internet]. 2020[cited 2020 Jun 07]. Preprint. doi: 10.1590/ SciELOPreprints.410

30. Lima CKT, Carvalho PMM, Lima IAAS, Nunes JVAO, Saraiva JS, Souza Rl, et al. The emotional impact of Coronavirus 2019-nCoV (new Coronavirus disease). Psychiatr Res. 2020;287 (112915):1-2. doi: 10.1016/j.psychres.2020.112915

31. Qiongni C, Mining L, Yamin L, Jincai G, Dongxue F, Ling W, et al. Mental health care for medical staff in China during the COVID-19 outbreak. Lancet Psychiatr. 2020;7(4):e15-e16. doi: 10.1016/S2215-0366(20)30078-X

32. Rolim Neto ML, Almeida HG, Esmeraldo JD, Nobre CB, Pinheiro WR, Oliveira C, et al. When health professionals look death in the eye: the mental health of professionals who deal daily with the 2019 coronavirus outbreak. Psychiatr Res. 2020;288(112972):1-3. doi: 10.1016/j. psychres.2020.112972 